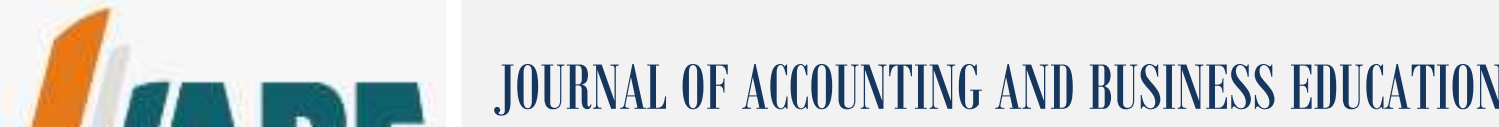 \\ P-ISSN 2520-7201 E-ISSN 2528-729X \\ E-mail: jabe.journal@um.ac.id \\ http://journal2.um.ac.id/index.php/jabe/
}

\section{Indonesian Government's Budgeting Responses during the COVID-19 Pandemic: Multi-Level Governance and Actor-Network Theory Perspectives}

\author{
Muliadi $^{1}$ \\ Aji Sofyan Effendi ${ }^{2}$ \\ Muhammad Ikbal ${ }^{3}$ \\ ${ }^{1,2}$ Department of Economics, Faculty of Economics and Business, Mulawarman University, Indonesia \\ ${ }^{3}$ Department of Accounting, Faculty of Economics and Business, Mulawarman University, Indonesia \\ email: muhammad.ikbal@feb.unmul.ac.id
}

Abstract: Indonesia is one country affected by Covid-19. The Indonesian government has responded this outbreak by implementing an open policy, not a total lockdown as implemented in several countries in Asia and Europe. Our study aims at exploring the budget policy response to the crisis conditions caused by the Covid19. This study focuses on three main issues related to how the central government budget policy responds to the local government level, how the government policies provide a stimulus for the private sectors and MSMEs, and the concrete steps in handling the education aspect. A qualitative paradigm through a netnographic approach was used to analyze these three issues. The data were collected using both mass media content and document analysis within a period of 1 April -31 August 2020. The analysis instruments consisted of a multi-level governance and actor-network theory. the research findings show that technology as a non-human actor plays an important role in building humans in solving problems existing in the multi-level governance involving central government, local governments, MSMEs, and education sectors. This study may provide some contributions on how to deal with the state crises due to the pandemic and other consequences.
Article History

Received:

21 October 2020

Revised:

10 February 2021

Accepted:

14 August 2021

Keywords

Netnography, Actor-

Network Theory, Multi-

Level Governance,

Budget, Crisis

Management, Covid-19

Citation: Muliadi, Effendi, A. S., \& Ikbal, M. (2021). Indonesian Government's Budgeting Responses during the COVID-19 Pandemic: Multi-Level Governance and Actor-Network Theory Perspectives. Journal of Accounting and Business Education, 6(1), 14-31

\section{INTRODUCTION}

Coronaviruses are a large family of viruses causing diseases in both humans and animals. In humans, the coronaviruses generally cause respiratory infections, from the common cold to serious illnesses, such as Middle East Respiratory Syndrome (MERS) and Severe Acute Respiratory Syndrome (SARS). A new type of Coronavirus was discovered in humans since December 2019 due to the outbreak in Wuhan China later known as Severe Acute Respiratory Syndrome Coronavirus 2 (SARS-COV2) and resulted in Coronavirus Disease-2019 (Covid-19). Because it is considered as a new disease, no immunity 
has developed in humans and eventually resulted in hospital treatments (Fakari \& Simbar, 2020). Covid19 is transmitted through both direct and indirect contact with humans and other materials. When viewed from the materials, the viruses have different survival rates. The quarantine period for Covid-19 is 14 days. It means that it will take 14 days from the infected person to show the symptoms.

Due to the current pandemic conditions, Indonesia has a unique case in response to the spread of Covid-19. While the other countries responded the pandemic by implementing a total lockdown, Indonesia chose to implement an open policy or Large-Scale Social Restrictions (known as PSBB/Pembatasan Sosial Berskala Besar). The open policy allow the country to continue its economy and result in less damage compared to others because the citizens continued working as usual that the businesses were less affected (Lau et al., 2020; Mahato et al., 2020). One reason why Indonesia moderately responded to the pandemic since the government wanted to soften the blow of Covid-19 pandemic on its economy (Fakari \& Simbar, 2020). The effect of closing businesses could result in the decreasing total output of $15 \%$ or more in both developing and developed economies. The outputs could even fall up to $25 \%$ for the medium economy (Nicola et al., 2020; Becker et al., 2016).

The Indonesian government has eventually realized that Covid-19 has huge impacts, both on health and socio-economy. To reduce the impacts, the government then issued a series of extraordinary policies to prioritize the state budgets on public health and safety as well as the business world protectionto save humans from various life aspects (eri Kurniawansyah HS*, Amrullah, M. Salahuddin, Muslim, 2020; Silalahi \& Ginting, 2020). To save the economy during this pandemic, the government has announced several policies (Silalahi \& Ginting, 2020). First, the President of the Republic of Indonesia has ordered all ministers, governors, and mayors to cut their non-priority expenditures in the State Budget (known as APBN/Anggaran Pendapatan dan Belanja Negara) and Regional Budget (known as APBD/Anggaran Pendapatan dan Belanja Daerah). Second, the President has asked both central and local governments to reallocate their budgets to accelerate the eradication of Covid-19 impacts from both health and economic perspectives through the Instruction of President Number 4 Year 2020 on Refocusing Activities, Budget Reallocation, and Procurement of Goods and Services to Accelerate the Covid-19 handling. Third, the president has asked both central and regional governments to guarantee and maintain the availability of basic commodities by ensuring that the purchasing power of people, especially the lower class. Fourth, the president has asked the Cash for Intensive Work Program to be reproduced and multiplied, with a condition that the program must comply the coronavirus prevention protocol, such as maintaining a safe physical distancing. The government has specifically focused on the cash for intensive work programs in several ministries, such as Ministry of Public Works and Public Housing, Ministry of Transportation, Ministry of Agriculture, and Ministry of Maritime Affairs and Fisheries. Fifth, the government has given an additional cash of IDR 50,000 per week per family to the cheap grocery card-holders for six months. Thus, they will receive IDR 200,000 per month. To implement the additional cash allocation on the cheap grocery cards, the government has provided the budget of IDR 4.56 trillion.

Since considered as a national disaster, the role of government is greatly needed. According to Taekratok et al., (2018), a disaster is described as a natural or human-induced emergency that suddenly results in broad negative economic and social consequences for the affected population. One of the main consequences is the influence of state budget and allocation of funds. When a disaster occurs, it is expected that the government makes some efforts to minimize the consequences. Putra \& Matsuyuki (2019) stated that when a natural disaster strikes, some people ask whether or not the government have made some efforts. Conversely, the citizens tend to automatically see the situation as a serious public problem urgently requiring the government actions. Thus, when a crisis occurs, it becomes the government's challenge to immediately respond to the citizens' demands. The affected community is eagerly awaiting the need for a quick response, while the available response options are limited (Avery et al., 2016). This is because decision-making and service delivery systems are not adequately effective and, in this situation, decisions need to be made immediately and outside the existing jurisdiction. The actions made to deal with the crises and consequences may become complex and uncertain. Moreover, general guidelines for crisis management did not exist (Bundy et al., 2017). According to Asatryan et al., (2017), 
the government's administrative capacity and resources will be overwhelmed by the people's demands in crises. When demands exceed the government's jurisdiction, higher jurisdiction levels will assist the lower ones by supporting or replacing the existing activities. This is determined by the budget and how to allocate funds. Taekratok et al., (2018) explained that there are many areas of budget looking at various political-economic structures and how to deal with passivity, policy, power, governance, and other selective matters.

The main purpose of this research is to explore the government's budget in response to the Covid19 pandemic in Indonesia. To meet the research objectives, this study will focus on the governance relationships at various levels of national and regional actors in Indonesia. In this study, budget crisis management will focus on the Covid-19 pandemic widely spread throughout the world in 2020. It is important to investigate the government's budget in response to the Covid-19 pandemic through the views of Actor-Network Theory (ANT) because many actors are involved in the budget policy determination, including human actors, such as politicians, state officials, as well as central and local governments. These actors are responsible for allocating the resources equally for different purposes, such as schools and health cares as well as both non-profit and profit organizations. Due to the explained backgrounds above, this study will present the related Actor-Network Theory (ANT), a research approach in the form of qualitative research using a Netnographic Approach, results and discussion, and finally, conclusions and limitations of this study.

\section{LITERATURE REVIEW}

The theoretical framework will present a literature review on crisis management, budgeting, and multi-level governance in the hierarchy of government in Indonesia. This is followed by the explanations of the selected theories, Actor-Network Theory (ANT), and why the theories are relevant.

\section{Crisis Management}

The spread of Coronavirus or Covid-19 is a crisis experienced by every organization, both corporate and non-corporate organizations (Burgner et al., 2020). Therefore, companies must prepare methods and strategies to prevent from the crisis which may become the obstacles for the companies running their businesses, or commonly known as crisis management (Gill et al., 2020). Before understanding the crisis management, it is necessary to figure out what a crisis is and how it can happen. Crisis is a very dangerous situation which can cause a big impact on everyone (Bundy et al., 2017). Crises can be in the form of outbreaks, natural disasters, technology, poor Management, terrorism, warfare, scarcity, etc. Meanwhile, crisis management can be defined as a process discussing an organization with a major event which threatens to harm the organization, stakeholders, or general public (Liff \& Erickson, 2017). There are three most common elements used in defining a crisis: threat to organization, surprise, and short time decision.

Crisis management also contains crisis communication. Crisis communication is the crisis management key success. Crisis conditions must be conveyed to all elements, consisting of society, company customers, and employees (Vardarlier, 2016).

\section{Budgeting in Crisis}

During the crisis, especially during the outbreak of disease pandemic, the resources related to the public budget are insufficient and uncertain. In such conditions, the government must manage the tradeoffs, cutbacks, reallocations, program terminations, organizational corrections, changes of rights, and non-negotiable contracts (Becker et al., 2016). Thus, the government and agency responses to the budget uncertainty affect many aspects, purchasing process, time of expenditure, and budget realization. According to the agency managers of Government Accountability Office (GAO) in 2017, the United States tried to be flexible in running the budgets, while the government agencies follow the controls made by the Congress to ensure the financial control and accountability. Due to several obstacles, such as the 
purpose of using funds and the number of funds, these will affect the distribution of funds during the budget period of one year.

Furthermore, the meaning of crisis management in an organization is that the organization properly responds the unexpected environmental changes, natural disasters, major accidents, or emergency events such as wars, terrorisms, earthquakes, nuclear plant accidents, tsunamis, and volcanic eruptions considered exceptions to the normal insurance claims. It means that the insurance premium will not be compensated for these events. Therefore, there is no risk management topic since originated from the insurance management, but a crisis management topic. An organizational crisis management is different from a national or administrative crisis management, because in the worst-case scenario, if something goes wrong, it can lead to bankruptcy and the organization will be destroyed (Khodarahmi, 2009).

\section{Actor-Network Theory}

Actor-Network Theory (ANT) is a theory often used as an approach or methodology for social studies (Shim \& Shin, 2016). In social theory, nature and social world exist in a constantly-changing interconnected network(Dedeke, 2017). The theory shows that all factors involved in a social situation are at the same level. Therefore, external social factors are not in the network. First, the term 'network' is used by Latour (2005: 131) ( in Burga \& Rezania, 2017) to describe the implicit boundary between characters which try to deal with a rule and how actors distribute and define roles and organize others to play those roles. Second, the term 'actor' indicates that something is acting or that an individual's activities are acceptable to others (Latour, 1996: 373 in (Hoffmann et al., 2017)). Roles can be characterized as technical, political, social, or bureaucratic matters and can also be organizations, people, or machines. Thus, the term 'actor-network' means that actors are networks and their actions and characters are transformed by human and non-human actors (Burga \& Rezania, 2017).

The budget preparation process, especially during emergencies, certainly has a special strategy and involves many parties, so to examine the government's budget in response to the Covid-19 pandemic by focusing on the MLG (multi-level governance) relationship between various national and local actors in Indonesia, the Actor-Network Theory (ANT) is used as human and non-human actors involved in the budget process. MLG focuses on the relationship between different levels of government where responsibilities for policy and implementation overlap (Zapata-Barrero et al., 2017). Moreover, this concept focuses on the vertical and horizontal relationships between different levels and at which nongovernment actors fit in the governance process (Hoffmann et al., 2017).

In general, ANT is more properly presented in the empirical studies involving the Accounting and State Finance since focusing on various actors in the actor-network system (Modell et al., 2017). In the process of government budgeting, there is a power relationship through the ANT perspective to explain how the power mechanism is created in an organization. The process is a collaboration between various actors which try to gather resources (Luscombe \& Walby, 2017). The budget in Indonesia has changed due to the Covid-19 pandemic in terms of allocation of funds and additional expenses related to the emergency budgets. The budget geographically allocates resources to the more affected areas, such as DKI Jakarta, East Java, Central Java, West Java, and several regions in Kalimantan and Sulawesi. These conditions can also affect many sectors in Indonesia such as SMEs, education, health care, as well as large and medium scale businesses. Through the ANT perspective, this study aims at examining the budget response to the Covid-19 pandemic by focusing on the MLG relationship between various central and local government actors in Indonesia.

\section{METHODS}

The main paradigm of this research is qualitative. According to Graneheim et al. (2017) the research approach, it can be either deductive, inductive, or abductive approach. Inductive approach is more appropriate than deductive approach when using a qualitative paradigm (Cho \& Lee, 2014) because the study is based on an empirical collection of the Indonesian government's budget response, which is then analyzed through the lens of actor-network theory. According to Bitektine (2008), qualitative 
methods are characterized by complexity due to the differences in readers' views. Because the results can be manipulated by the researchers' interpretation, the results obtained are not objective (Moretti et al., 2011). To obtain higher validity and reliability in qualitative research results, it can create in-depth knowledge of the research area (Noble \& Smith, 2015). This research would like to conduct an in-depth analysis to the government's responses in the form of budget policies during the Covid-19 pandemic situations and conditions, focusing on the multilevel governance (MLG) relationships between various national and regional actors in Indonesia. Meanwhile, the empirical data were collected between 1 April 2020 and 31 August 2020.

The research data were collected from various media contents by considering the pure truth based on information from the other similar media. The media are selected based on reputation and independence of various media over the past 10 years. Interpretations were the made based on the results of media contents to have a broad narrative and easy to understand in both academic and public domain.

\section{Netnographic Approach}

Kozinets, (2015) defines netnography as an extension of ethnographic approach. "Netnography, or ethnography on the Internet, is a qualitative research methodology adapting the ethnographic research techniques to study the emerging cultures and communities through the computer-mediated communication". In 2000, Hine published a book entitled Virtual Ethnography which introduced the idea of using internet as a research area in which the researchers can use the traditional ethnographic approaches in virtual spaces (Sandlin, 2007). Using an internet-based approach is very effective because the Covid-19 pandemic has prevented using the primary data, for example through interviews. The information obtained from internet is constantly updated and allows researchers to obtain the relevant data. However, netnography has its challenges. The virtual world consists of large number of data, which can lead to the excessive information for the researchers. Thus, the researchers should carefully select and evaluate relevant data for the research questions. One recommendation from Kozinets, (2015) is to first look for an overview on the related data, before deciding which data to use. However, netnography, in this case, provides a good access to both primary and secondary data resulting in a rich understanding of public accounting sector (Aleksandrov et al., 2018), especially during the pandemic in which most information is internet-based and can be seen in the press releases.

\section{Mass Media Analysis}

Mass media plays an important role in the development of a country. Political parties and governments see mass media as a powerful and influencing source. The businessmen even recognize the importance of media not only as advertising but also content-influencing channels (Feezell, 2018). News provided in media can affect the stock prices, cause the sales to fall, cause the companies to fall, etc. (Strycharz et al., 2018). Besides, media also provide the latest information about changes in budgeting policies in Indonesia during the Covid-19 pandemic. Mass media analysis is a part of content analysis widely using the research methodology. Content analysis is a research method used to study a broad range of narratives, which can be documented from various organizations as well as contents from newspapers and magazines (Lytvynenko et al., 2017).

A mass media analysis is an "objective" research method (Jones et al., 2016). Mass media can provide information related to areas affected by the Covid-19 pandemic and resource allocations to those areas. However, according to Vladimirova et al., (2019), it is impossible to produce the completely objective outcomes, especially when it comes to media because media are open to different interpretations and not completely objective. A mass media analysis can provide insights to the popular cultures represented in the related media and allow researchers to explore how the contents of media describe the society and potential effects by identifying trends and having a thorough competitor analysis (Sheng \& Lan, 2019). 


\section{Document Analysis}

One way to collect the data in content analysis using the Netnography approach is through document analysis (Tavakoli \& Wijesinghe, 2019). Document analysis is a procedure to evaluate or review documents, not only in the electronic forms, such as materials transmitted through internet but also in printed versions. Document analysis involves data interpreted and examined to gain understanding and develop empirical knowledge (Whalen, 2018). Document analysis is applied to understand government reports, especially those related to budgeting. Document analysis largely serves as a complement to diverse research methods (Whalen, 2018) and will be the case in this study. Document analysis will complement a mass media analysis to follow up on various government programs related to the handling of Covid-19 pandemic in Indonesia.

\section{RESULTS}

\section{The outbreak of Covid-19 pandemic in Indonesia}

Based on the explanations above, the early emergence series of Covid-19 pandemic outbreak are highly familiar to the world community. China is listed as the country first reporting the Covid-19 cases in the world. As quoted from the Kompas online mass Media (https://bebas.kompas.co.id) which reviewed the first phase, China reported the existence of this new disease on December 31, 2019. At the end of 2019, the World Health Organization (WHO) office in China received a notification related to a form of the unknown-cause pneumonia. The acute respiratory infection which attacks lungs was detected in the city of Wuhan, Hubei Province, China. According to the authorities, some patients were traders operating at the Huanan Fish Market.

This Kompas online media page (https://bebas.kompas.co.id) reviewed that the President of the Republic of Indonesia, Joko Widodo, officially announced the first case of Covid-19 in Indonesia at the State Palace on March 2, 2020. Two Indonesian citizens who had the positive Covid-19 made a contact with some Japanese citizens coming to Indonesia. An Indonesian citizen first died caused by the Covid-19 was in Solo on March 11, 2020 at the age of59-year-old man, after attending a seminar in Bogor of West Java on February 25-28, 2020. In the same week, patient \# 01 and patient \# 03 were declared cured. On March 13, 2020, they were officially declared cured and allowed to leave the hospitals the first person infected by the Covid-19 was cured in Indonesia. Patient \# 02, an elderly aged 64 years old, has also managed to overcome the Covid-19.

A month after the emergence of Covid-19 in Indonesia, for the first time, it was recorded that the cure rate for people with Covid-19 was greater than the number of people who died from the virus. Kompas online mass media (https://bebas.kompas.co.id) wrote that on April 16, 2020, the data from the Task Force for accelerating the handling of Covid-19 showed that 548 patients recovered, while 496 patients died. However, data on the patients recovered from Covid-19 exceeding the number of died patients was not a sign that the outbreak of Covid-19 will be over soon in Indonesia. So far, the number of Covid-19 cases in Indonesia continuously increases. in few months after the first officially declared, that the number of Covid-19 cases in Indonesia has reached more 5,500 cases. 

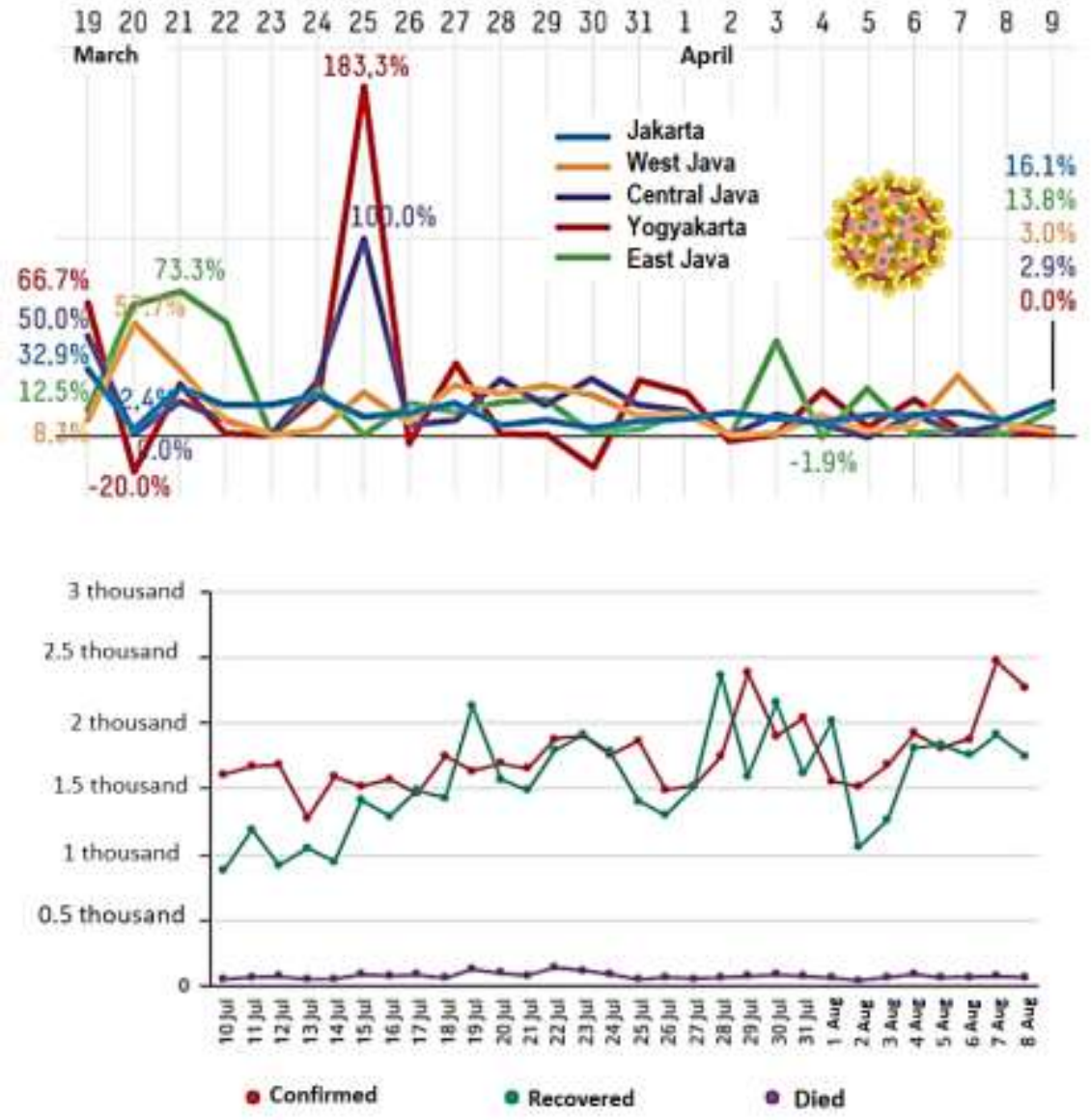

Figure 1. Movement and Addition of Positive Covid-19 Cases in Indonesia (Source: covid-19.go.id)

\section{Government Policy: Large-Scale Social Restrictions}

The results of mass media analysis in April 2020 showed that the COVID-19 cases have continuously increased in various regions and urged the local governments to take specific actions, such as implementing the Large-Scale Social Restrictions in various regions. The Large-Scale Social Restrictions are listed in the Minister of Health Regulation No. 9 Year 2020, on the Guidelines for LargeScale Social Restrictions in the Context of Accelerating the Covid-19 handling. This Minister of Health Regulation is derived from the Government Regulation No. 21 Year 2020 on the Large-Scale Social Restrictions in the Framework of Accelerating the Covid-19 Handling.

Based on the detik online media page (https://news.detik.com: April 20, 2020), there are six core PSBB activities in Article 13 of the Minister of Health Regulation No. 9 Year 2020:

1) School and working activities

2) Restrictions on religious activities

3) Restrictions on activities in public places or facilities

4) Limitations of social and cultural activities

5) Limited transportation modes

6) Restrictions on other activities specifically related to the defense and security aspects

This regulation does not contain sanctions for people who violate the Large-Scale Social Restrictions. However, the implementation of Large-Scale Social Restrictions through the governor, mayor, and regent regulations contains sanctions for communities and business entities if not complying the social restrictions. Some areas with a very high growth of positive Covid-19 patients will apply the 
Large-Scale Social Restrictions. The implementation of Large-Scale Social Restrictions in Indonesia is based on the following reviews made by Detikcom Media (https://news.detik.com: 20 April 2020):

1) The Large-Scale Social Restrictions implemented in Jakarta. Effective date: 10-23 April 2020, possibly extended Sanctions: One year in prison and a fine of IDR 100 million.

2) The Large-Scale Social Restrictions implemented in Bandung. Effective date: 22 April-5 May 2020. Sanctions: Verbal warning, warning, Police records against violators, detention of identity cards, restrictions/termination/dissolution of activities, temporary closure, suspension, and license revocation.

3) The Large-Scale Social Restrictions implemented in Surabaya. Effective date: The Governor of East Java has sent a request to implement the Large-Scale Social Restrictions to the Minister of Health. Terawan Sanctions: Still learning from the other Local Police Department.

4) The Large-Scale Social Restrictions implemented in Tangerang. Effective date: 18 April-3 May 2020. Sanctions: Verbal warning, written warning, temporarily forced confiscation of goods or tools having a potential to cause violations, temporary forced suspension of activities, suspension of permits to revocation of permits.

5) The Large-Scale Social Restrictions implemented in Makassar. Effective date: 24 April-7 May 2020. Sanctions: Penalties according to statutory provisions including the administrative and criminal sanctions.

\section{Government Policy (again): New Normal}

After seeing the decline in economic conditions since the implementation of Large-Scale Social Restrictions in early April 2020 until June 2020, the Indonesian government issued a new policy, namely the adaptation of a new life (New Normal). New Normal can be considered necessary because people need to continue their activities even with different cultures and behaviors from the previous period. The government also states that this policy is not arbitrary, because there are some underlying scientific factors. The plan to implement the new normal in Indonesia, of course, will have an impact on then previously stopped or limited several activities and will reopen several regulations. These activities include economic activities, such as in shopping centers up to the worship places.

Even though until now there is still no vaccine to deal with Covid-19, the government considers that the implementation of this new normal can still make people productive. As reviewed from Kumparan online mass media (https://kumparan.com/), Achmad Yurianto as the spokesman for the Covid-19 handling in Indonesia, a new order (new normal) needs to be implemented so that people do not give up on the Covid-19 pandemic. "Now the only way to do is not giving up doing nothing, but we have to maintain our productivity in this situation. To be still productive but safe from the Covid-19, a new order is greatly required," said Achmad Yurianto (https://kumparan.com/). Reporting from the official website from the Ministry of Health (https://www.kemkes.go.id/), Achmad Yurianto said that the meaning of new normal is new habits and behaviors based on the adaptation to civilize a clean and healthy lifestyle. This is the meaning of new normal in Indonesia. Keep your health and don't forget to wear your mask when traveling.

\section{Economic Consequences}

On Wednesday, August 5, 2020, the Statistics Indonesia (https:/bps.go.id) released the Indonesian economic growth figures for the second quarter of 2020. As predicted, the Indonesian economy has decreased by -5.32 percent (year by year). The decrease was more than the previous prediction made by the Minister of Finance. The minister has predicted that the Indonesian economic growth in the second quarter will experience a decrease ranging between -3.5 and -5.1 percent. The negative figure in this quarter had added to the poor economic growth records in 2020. In the first quarter, the Indonesian economic growth has been recorded at 2.97 percent. This achievement was lower than the previous prediction by 5 percent. The economic growth in the first and second quarters, which tends to decline, cannot be separated from the influence of Covid-19 pandemic lasted more than four months. Since first announced on March 2, 2020, to August 6, 2020, the number of positive Covid-19 cases in Indonesia has 
reached 118,753 people. What are the details of Covid-19 impact on the Indonesian economic movements?

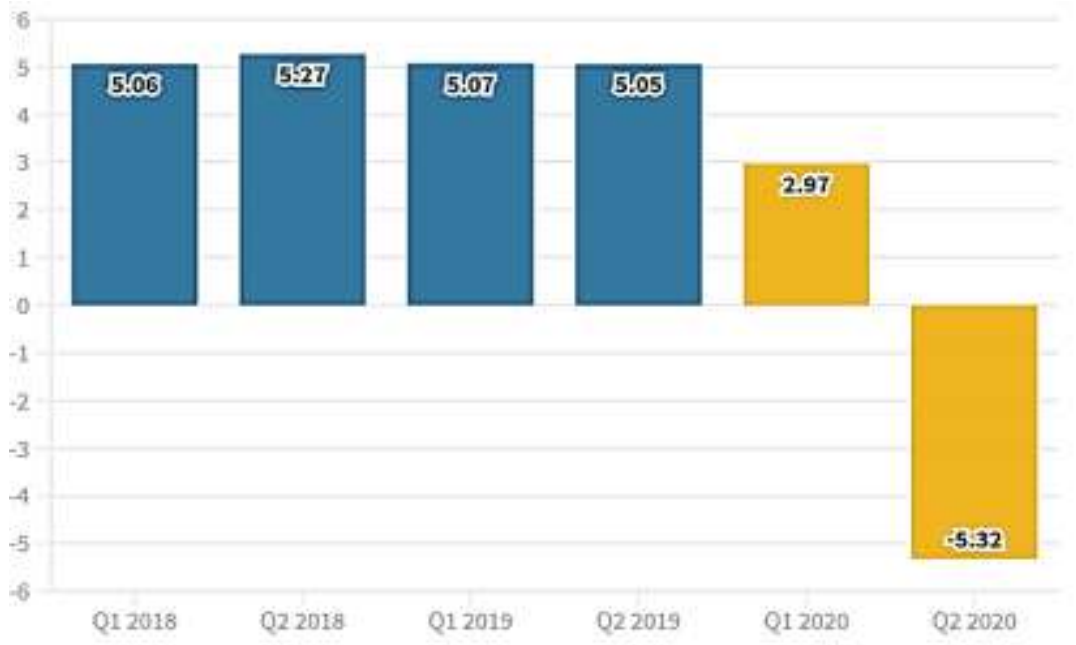

Figure 2. Indonesian Economic Changes in Quarter I and Quarter II of 2018-2020 based on the Previously Normal and Recent Conditions of Covid-19 Pandemic (Source: Statistics Indonesia, 2020)

The Indonesian economic growth in the first and second quarters of 2018-2019 was around 5 percent. The decline started when the pandemic began in 2020. Growth in the first quarter of 2020 was recorded at 2.97 percent. If recalculated, at same quarter of 2019, the growth was recorded5.07 percent. It means that there is a difference of -2.1 percent. Meanwhile, the difference in the second quarter was larger. If calculated between the first quarter of 2020 (-5.32 percent) and the second quarter of 2019 (5.05), there was a difference of -10.37 percent. The record figures were different when compared to the "normal" or pre-Covid-19 conditions. When comparing the first and second quarters of 2019 with those of 2018, the figures tend to be stable with a fairly small difference (https://tirto.id/: 11 August 2020).

\section{DISCUSSION}

By using the ANT and MLG theoretical perspectives, the Indonesian government's budget policies in response to the Covid-19 pandemic spread throughout Indonesia were explored using in-depth analysis and obtained the empirical results from various sources in various national mass media. This analysis includes the Budgeting Responses during the pandemic, budget allocations to local governments, how the budget interventions supported the financially-affected private companies, and how the budgetary measures are anticipated in education sectors.

\section{Budgeting responses to the occurring pandemic}

The Ministry of Finance has prepared the budget to handle the outbreak of Covid-19 until 2021. Meanwhile, the government has opened opportunities to allocate funds to handle the Covid-19 pandemic until 2022. In August 2020, the Government has prepared the 2021 State Budget Draft (known as RAPBN/Rancangan Anggaran Pendapatan dan Belanja Negara). The government has also designed one supporting package to handle the continuing Covid-19 pandemic in the following year. The 2021 State Budget Draft is planned submitted to the House of Representatives (known as DPR/Dewan Perwakilan Rakyat) in September 2020. The government hoped that this draft budget could be the right step for the government in supporting the business world and communities affected by the Covid-19 pandemic. As reviewed in Katadata online media (https://katadata.co.id/ 21 April 2020), the budget for handling the Covid-19 pandemic was likely to increase in the following years due to the widening budget deficit of 
above 3\% as regulated in the Government Regulation in Lieu of Law (known as Perppu/Peraturan Pemerintah Pengganti Undang-Undang) No. 1 Year 2020 on handling the Covid-19 pandemic and its impacts on economy. The Government Regulation In lieu of Law will be valid for three years starting from 2020 up to 2022. In 2023, it is expected that the State Budget deficit can be controlled below 3\%, by Law Number 17 Year 2003 on State Finance.

\section{Budget Allocation Policies in the Affected Areas}

As reviewed in the national media Detikcom (https://travel.detik.com/dated 3 August 2020) that the National Disaster Management Agency has released a list of districts/cities with high risk spread of the Covid-19 pandemic. Until July 26, 2020 there was a positive Covid-19 increase from 35 to 53 regencies/cities included in the red zone. "Based on the results of 15 public health indicators, 53 municipalities were in high risk of Covid-19 classified into 185 moderate zones and 182 low zones. Meanwhile, 51 regencies/cities which were classified into the green zone have no new cases for the last 4 weeks and the cure rate of 100 percent. However, there were 43 regencies/cities had no new cases", said a member of Covid-19 Handling Task Force Expert Team, Dewi Nur Aisyah, in a BNPB broadcast. From this news story, it was seen that apart from the capital city of Jakarta and several areas in Java Island, some other areas have also been heavily invected by the Covid-19 in most provinces throughout Indonesia classified into the red zone due to the rapid spread of Covid-19.

The government is highly responsive in preparing a budget strategy to handle such conditions. In addition to the state budget allocations, the government also allocates budgets to local governments, through the Regional Budget transfers. The regional budget reallocation for handling the Covid-19 has reached IDR 63 trillion. This was based on the data held by the Ministry of Home Affairs. This reallocation was used for three main sectors during the outbreak of Covid-19 pandemic, including the capacity building for health sector, social safety, and stimulus dealing with the economic impacts. The total budget used for the development of health sector was approximately IDR 25 trillion. Meanwhile, the reallocation budget used for social safety was IDR 26 trillion, and approximately IDR 10 trillion was used for the economic stimulus.

As previously mentioned, several regions have received the direct assistance policy packages for the communities. As reviewed in Kontan media (https://national.kontan.co.id/6 August 2020), the Government ensured to provide the direct cash assistance (known as BLT/Bantuan Langsung Tunai) to employees with the salaries of below IDR 5 million per month. The direct cash assistance to employees in the form of cash of IDR 600,000 was directly transferred to each employee who deserved receiving the assistance. The Chief Executive Committee for Handling the Covid-19 and Economic Recovery, also the Minister for State-Owned Enterprises, Erick Thohir, stated that the direct cash assistance to employees with the salaries of below IDR 5 million per month was applicable with certain conditions.

The government through the Ministry of Finance changed the social assistance distribution scheme in the form of direct cash assistance for village funds. This regulation was stated in the Minister of Finance Regulation Number 50/PMK.07/2020 concerning the Second Amendment to 205/PMK.07/2019 on Village Fund Management. Through this regulation, the government increased the amount and time frame for providing the direct cash assistance through the village funds to the communities. So, the total direct cash assistance, which was previously IDR 1.8 million per beneficiary family (known as KPM/Keluarga Penerima Manfaat), has been increased to IDR 2.7 million/beneficiary family.

This effort was the initial stage of MLG system made by the Indonesian government because the highest level (government) have assisted the lower levels (sectors and regions) (Zapata-Barrero et al., 2017). These budget measures and policies were intended to reduce the spread of Covid-19 and anticipate the vulnerability of life due to the outbreak of Covid-19 In this case, to both public actors (Laasch, 2019). This is also an example of vertical relationship (Zapata-Barrero et al., 2017) between different levels as explained by ANT, because the ministry was lack of authority over the power, resources, and government structures in responding to the changes in public policy (Zapata-Barrero et al., 2017). Therefore, different actors and levels are required to work together to cope with the changes resulted from this pandemic (Shim \& Shin, 2016). As previously mentioned, Indonesia has developed the MLG system at the national, 
provincial, and district/city levels to explore the relationship between different levels of government and interactions with different types of the involved actors (Burga \& Rezania, 2017). For example, the government has abolished the jurisdiction system to create collaboration between individuals and government. In summary, this budget response affected not only districts and cities, but also public and private companies, universities, and other institutions within the central government.

\section{Support for private sectors and MSMEs}

The Covid-19 pandemic is not only considered as a health disaster, but also has caused chaos in the economic sector. Not only large industries, the Covid-19 pandemic has also greatly impacted the SMEs in Indonesia. A recent study said that the Covid-19 would cause Indonesia to experience a decline of $0.1 \%$ in its economic growth in 2020. The real impacts caused by Covid-19 on the SME sector in Indonesia are as follows.

\section{Difficulties for private sectors and MSMEs in Facing the Covid-19}

The impacts of Covid-19 pandemic have caused almost $70 \%$ of micro, small, and medium enterprises (MSMEs) out of businesses. This has a potential to continuously increase if the pandemic continues over a long period. Some of the real impacts have been felt by the MSMEs as reviewed from the following Detikcom, Kompas, and Kumparan mass media sources:

\section{a) The decrease in Buying and Selling Activities}

Social distancing which was intended for people to avoid a wider spread of Covid-19 has more or less contribution to reduce the trading activities in communities, such as warteg entrepreneurs in Jakarta. The results of interviews with the head of Warteg Nusantara Community (known as Kowantara/Komunitas Warteg Nusantara), Mukroni, it was stated that the Covid-19 pandemic has made the turnover of warteg entrepreneurs in Indonesia, especially in Jabodetabek, decreased by 50 percent. Fortunately, according to research conducted by the Center for Economic and Social Studies (CESS) and the Center for Micro and Small Enterprise Dynamic (CEMSED), the SMEs in Indonesia were unique because they could develop and survived during the crisis. This was proven by the initiatives made by the warteg entrepreneurs who preferred to continue operating by changing their selling ways by serving through the packaged (take-home) purchases (take home) instead of on-the-spot serving purchases.

\section{b) Difficulties in Obtaining Raw Materials}

The social distancing policy chosen by the Indonesian government has disrupted the production activities. Some companies have adopted a Work from Home policy and some others decided to lay off their employees. According to the latest data from the Jakarta Manpower, Transmigration, and Energy Office, 30,137 workers reported lost their jobs due to the mass layoffs, while 132,279 other workers lost their incomes because they were sent home without wages. The domino effects of the laid-off workers could be seen from the extreme decline of production capacity. This condition has led to the scarcity of raw materials for home industry production and eventually resulted in extreme price increases. For example, the SME sectors for cake and bread makers were confused by the soaring prices of eggs and sugar. As a result, the product selling price also increased. This choice was considered risky as the people's purchasing power was sluggish.

\section{c) Hampered Distribution}

The government continuously strived to maximize the distribution channels throughout Indonesia through a massive infrastructure development in Indonesia. The project has even been started since the President, Joko Widodo, served for the country in his first term. The results were quite significant. The distribution channels were faster, the price gap could be cut, and people's economic pace got faster. However, the Covid-19 has "destroyed" them all. According to data from the Indonesian Toll Road Association (known as ATI/Asosiasi Jalan Tol Indonesia), the average daily traffic of all toll roads in Indonesia has decreased between 40-60 percent since the beginning of March 2020. The extreme decline occurred in the Jabodetabek areas. In February 2020, the number of passing vehicles reached 3.19 million vehicles, while at the end of March; there were only 1.06 million passing vehicles. This condition was expected to continue during the Covid-19 pandemic. The cessation of distribution activities was certainly 
detrimental to the SME business actors. They were confused distributing their products, especially for those beginning to expand their markets outside of the regions, or even across islands.

\section{d) Exposed Service Providers to the Impacts of Covid-19}

Not only SMEs engaged in home production sectors, but also those engaged in services were reported having a significant turnover decline. For example, many barbers were forced to lose their incomes due to the social distancing policies. Those working as casual daily laborers, such as construction workers, make-up artists, wedding organization workers, wedding photographers, and others were reportedly having trouble earning incomes because several projects had to be postponed due to the Covid19 pandemic. Luckily, the government has recently been braved enough to take a policy of not imposing lockdowns, so that some SMEs in the regions still have the opportunities to find ways to 'survive'. Besides, several other policies were considered quite helpful for the SME actors, for example providing more flexible credits, free and discounted electricity of up to 50 percent, and easy capital injection programs. This can also be seen from the steps taken by the Financial Services Authority to issue a countercyclical policy as stated in press release No. HM.4.6/32/SET.M.EKON.2.3/03/2020 by the Coordinating Ministry for Economic Affairs of the Republic of Indonesia.

\section{Budget Response from Government}

The government has launched several assistance programs for people affected by the Covid-19 pandemic. The assistances were in various forms, ranging from those in the form of cash, electricity tokens, to telephone credits. Some of these assistances are still distributed and ongoing. 6 government assistances for the Indonesian people during the Covid-19 pandemic are as follows:

1) Pre-employment Card. The government has provided assistance in the form of Pre-employment Card, in which the recipient will receive IDR 3,550,000 during the program. The Pre-Employment Card is a competency development program for the job seekers and workers or laborers who have been permanently terminated. It is known that the details of the assistance include a training assistance fee of IDR 1 million which cannot be disbursed (only for training costs), the incentives to complete the training of IDR 600,000 per month for 4 months, and for job survey of IDR 150,000.

2) MSME working capital assistance. The government has also provided assistances to the MSME actors by distributing funds up to IDR 2.4 million, given in one transfer through the recorded accounts of MSME actors. The banks distributing those assistances are Bank Rakyat Indonesia (BRI) and Bank Negara Indonesia (BNI). The distributions for the first phase of capital assistances to beneficiaries have been previously made. However, several requirements must be fulfilled by the MSMEs, namely the business actors must be the Indonesian citizens, having a Citizen Identification Card (known as KTP/Kartu Tanda Penduduk), having a micro business proven by a proposal letter and the proposers are not the members of State Civil Apparatus, Indonesia National Force/Indonesian National Police, or the employees of State-Owned or Regional-Owned Enterprises /.

3) Salary subsidies. The government has assisted the private employees with salaries of less than IDR 5 million and active participants in BPJS Employment. The distributed assistances were in the form of cash worth IDR 600,000 per month. The recipients cumulatively got a total of IDR 2.4 million gradually transferred to their accounts. The employees receiving the assistances were not differentiated based on their employment status, whether contract or permanent employees. Not only to the private employees, were assistances also given to the honorary employees registered in $B P J S$ employment with the salary of below IDR 5 million.

4) Cash Social Assistance. The Cash Social Assistance recipients were in Kulonprogo Regency. The government through the Ministry of Social Affairs has distributed the assistances to the communities, namely Cash Social Assistance (known as BST/bantuan Sosial Tunai) worth IDR 500,000. The distribution of this assistance was provided to help people affected by the Covid-19. The assistances were targeted for the families classified into the Beneficiary Families (known as KPM/Keluarga Penerima Manfaat) of the Non-Cash Food Assistance Program (known as BPNT/Bantuan Pangan Non-Tunai). 
5) Electricity token from the State Electricity Company. Not only social assistance, the government has also provided free electricity subsidies for the $450 \mathrm{VA}$ users and 50 percent discount for the $900 \mathrm{VA}$ users. The government has also expanded incentives for the electricity bills. The targeted customers were those in social, business, and industrial segments.

6) Money Credit for the State Civil Apparatus. The government has also provided various credit allowances aiming at supporting the working activities recently made at home. This IDR 400,000 credit assistance was applicable for the State Civil Apparatus. The accepted amount of assistance for data and communication packages was for the officials at the levels of echelon I and echelon II equivalent to IDR 400,000 per month. Meanwhile, the officials at the levels of echelon II or equivalent and below have received IDR 200,000 per month. Apart from the State Civil Apparatus, the students participating in the distance learning activities (known as PJJ/Pembelajaran Jarak Jauh) and the communities involved in online activities incidental in nature were also given free data packages.

As previously stated, the private companies or MSMEs are also the components of MLG system functioning through collaboration that all parties are necessarily considered in times of crisis (Shim \& Shin, 2016; Zapata-Barrero et al., 2017). Furthermore, the government has also implemented some regulations covering various discounts for the Pertamina fuel purchases for online motorcycle taxis. Companies in Indonesia have played an important role in terms of actor-network (ANT) because they have made various contributions to the Indonesian economy in terms of employment (Shim \& Shin, 2016). When viewed from the MLG system, the company is at a local level (Zapata-Barrero et al., 2017).

Reviewed from Talenta online media (https://www.talenta.co/), several companies have been recommended allowing the workers not to go to the office and stay at home when they are sick until they are fully recovered. Even if the employee is found to have new symptoms in the form of coughing and shortness of breath, the company will recommend the employee to stop working and undergo a medical examination at the hospital. Thus, companies must have provided the Human Resources Information System (HRIS) features to help employees' needs. The freedom offered by the self-service mobile employees, such as Talenta can meet the needs of employees at these times (https://www.talenta.co/). As mentioned earlier, companies as actors have provided labors and minimize their spending to the state in terms of subsidies (Burga \& Rezania, 2017) and moderated pressures from the government to intervene (Zapata-Barrero et al., 2017).

\section{Interventions in Education Sectors}

The outbreak of Covid-19 has affected almost all countries throughout the world, even in all sectors, including economic, political, and education sectors. In education sectors, for example, all schools in 27 cities and regencies especially in West Java were forced to close due to the Covid-19 pandemic following all regions in Indonesia at the end of March 2020. The face-to-face learning has been turned into distance learning (known as PJJ/pembelajaran Jarak Jauh) both online and offline. How will the education process take place if face-to-face is eliminated? Due to these changes, almost all elements were shocked and confused to find the proper methods to perform the learning processes in response to the consequences of this Covid-19 pandemic. Various problems also arose at the beginning of the changes due to this pandemic, starting from the readiness of education providers to the problems arising in various fields, such as the obstacles to access for students in both online or offline learning processes with the limited existing infrastructure.

The government in this case as a policymaker has an important role in overcoming these various problems, namely to protect the rights to learn for the communities, especially for students. The government must also ensure that all regions have a complete and effective infrastructure in facilitating the students' learning activities, both in central and local governments, and even up to the village administration levels, must be present to face the problems, especially in the education sectors. Although the government has made various efforts to deal with the Covid-19 pandemic, by issuing several policies related to education starting from issuing regulations so that learning can be more flexible and not stressful for the students, several rules are essentially to help ease the burdens. The Indonesian citizens 
were greatly affected by the Covid-19 pandemic from the financial side, yet their rights to learn as Indonesian citizens should be well protected. However, it is greatly expected that the government will take various other steps which are more effective to support various activities in the education sectors.

The President, Joko Widodo has set the deficit rate in the draft of 2021 State Budget Posture at $5.2 \%$ from the gross domestic product (GDP). The widening deficit resulted in the additional spending on several budget items. This included the allocations for the education and health budget certainly larger than usual. As reviewed from CNBC media (https://www.cnbcindonesia.com/ 28 July 2020), the Minister of Finance, Sri Mulyani Indrawati, in a press conference after attending the limited meeting has stated "Education and health which increased the deficit here is a mandatory budget." Thus, there will be an increase in the budget allocation for both education and health sectors in the next fiscal year of 2021. "We use the budget to improve both education and health sectors of respectively more than IDR 30 trillion and IDR 9 trillion due to this additional deficit".

In short, one of the most important actors to invest in education is technology, which has played an important role in the learning processes during the period of Covid-19 pandemic. The education sector budget will target various technology platforms, research funding, and locus expansion. The 2020 learning year has provided students with various opportunities to enroll in education in a faster manner and also deepens the students' knowledge in certain fields. Due to the layoffs, dismissals, and traveling restrictions, many students have taken the opportunities to conduct their self-study at home. One of the most used platforms during the pandemic was Zoom. Similar to companies, schools have been operated at the local level. It means that the higher levels, such as different governments and authorities need to financially help lower levels by functioning the MLG system (Shim \& Shin, 2016) in these uncertain times.

\section{CONCLUSION}

As explained earlier, this research focuses on the analysis of budget policy responses made by the Indonesian government when facing the Covid-19 pandemic widely spread throughout Indonesia. The empirical data were initially presented ranging from data on the outbreak of Covid-19 starting from early March and continuously developing to August 2020. After the data on the spread of Covid-19 suspects have continued to increase, the government began to issue a policy called Large-Scale Social Restrictions (known as PSBB/Pembatasan Sosial Berskala Besar). After several months, it impacted on the weakening economy, until the government issued a new policy called adaptation to new life or (New Normal). As previously predicted that there would be an economic impact due to the outbreak of Covid-19, the government then released the Indonesian economic growth figures in the second quarter of 2020, the Indonesian economy has decreased by -5.32 percent (year by year).

Based on the empirical data and research purpose aiming to analyze the budget policy responses made by the Indonesian government in facing the Covid- 19 pandemic, this research focused more on several government responses starting from the affected regencies/cities up to the budgeting responses on private, MSME, and education sectors.

The regional budget (known as APBD/Anggaran Pendapatan dan Belanja Daerah) reallocation for handling the Covid-19 has reached IDR 63 trillion. This is based on data provided by the Ministry of Home Affairs. The budget reallocation will be used for three main elements during the Covid-19 pandemic including the capacity building for health sector, social safety, and stimulus dealing with the economic impacts. The total budget used for the development of health sector is around IDR 25 trillion, and some regions have even received the policy packages for direct assistance to the society. The government through the Ministry of Finance has changed the social assistance distribution schemes (known as bansos/Bantuan Sosial) into the direct cash assistance (known as BLT/Bantuan Langsung Tunai) for the village funds. The government has increased the length and time frame to provide the direct cash assistance as the village funds to the society. 
In education sector, the government, in this case, the policymaker has an important role in overcoming various problems to protect the people's rights to learn, especially for students. The present Indonesian President, Joko Widodo, has set the deficit rate in the Draft of 2021 State Budget Posture at $5.2 \%$ of gross domestic product (GDP). The widening deficit results in the additional spending on several budget items. This includes the budget allocations for education and health certainly larger than usual. The Minister of Finance said that there would be some increasing budget allocations for both education and health sectors in the upcoming fiscal year of 2021.

Thus, this study suggests the government to immediately respond various problems due to the multidimensional crises caused by the outbreak of Covid-19 pandemic. There are some limitations in this study, ranging from the limited research time to the difficulties in collecting the data in this limited period. This research has important implications for the government to evaluate the policies for handling the crises happening in Indonesia which is recently also hit by the global disasters.

\section{REFERENCES}

Aleksandrov, E., Bourmistrov, A., \& Grossi, G. (2018). Participatory budgeting as a form of dialogic accounting in Russia: Actors' institutional work and reflexivity trap. Accounting, Auditing and Accountability Journal, 31(4), 1098-1123. https://doi.org/10.1108/AAAJ-02-2016-2435

Asatryan, Z., Heinemann, F., \& Pitlik, H. (2017). Reforming the public administration: The role of crisis and the power of bureaucracy. European Journal of Political Economy, 48, 128-143. https://doi.org/10.1016/j.ejpoleco.2016.08.004

Avery, E. J., Graham, M., \& Park, S. (2016). Planning Makes (Closer to) Perfect: Exploring United States' Local Government Officials' Evaluations of Crisis Management. Journal of Contingencies and Crisis Management, 24(2), 73-81. https://doi.org/10.1111/1468-5973.12109

Becker, S. D., Mahlendorf, M. D., Schäffer, U., \& Thaten, M. (2016). Budgeting in Times of Economic Crisis. Contemporary Accounting Research, 33(4), 1489-1517. https://doi.org/10.1111/19113846.12222

Bitektine, A. (2008). Prospective case study design: Qualitative method for deductive theory testing. Organizational Research Methods, 11(1), 160-180. https://doi.org/10.1177/1094428106292900

Bundy, J., Pfarrer, M. D., Short, C. E., \& Coombs, W. T. (2017). Crises and Crisis Management: Integration, Interpretation, and Research Development. In Journal of Management (Vol. 43, Issue 6). https://doi.org/10.1177/0149206316680030

Burga, R., \& Rezania, D. (2017). Project accountability: An exploratory case study using actor-network theory. International Journal of Project Management, 35(6), 1024-1036. https://doi.org/10.1016/j.ijproman.2017.05.001

Burgner, A., Ikizler, T. A., \& Dwyer, J. P. (2020). Covid-19 and the inpatient dialysis unit managing resources during contingency planning pre-crisis. Clinical Journal of the American Society of Nephrology, 15(5), 720-722. https://doi.org/10.2215/CJN.03750320

Cho, J. Y., \& Lee, E. H. (2014). Reducing confusion about grounded theory and qualitative content analysis: Similarities and differences. Qualitative Report, 19(32), 1-20.

Dedeke, A. N. (2017). Creating sustainable tourism ventures in protected areas: An actor-network theory analysis. Tourism Management, 61, 161-172. https://doi.org/10.1016/j.tourman.2017.02.006

eri Kurniawansyah HS*, Amrullah, M. Salahuddin, Muslim, S. N. (2020). Konsep Kebijakan Strategis Dalam Menangani Eksternalitas Ekonomi Dari Covid - 19 Pada Masyarakat Rentan Di Indonesia. 
Indonesian Journal of Social Sciences and Humanities, Vol. 1 No.(2), 130-139. file:///C:/Users/User/Downloads/fvm939e.pdf

Fakari, F. R., \& Simbar, M. (2020). Coronavirus pandemic and worries during pregnancy; a letter to editor. Archives of Academic Emergency Medicine, 8(1), 8-9. https://doi.org/10.22037/aaem.v8i1.598

Feezell, J. T. (2018). Agenda Setting through Social Media: The Importance of Incidental News Exposure and Social Filtering in the Digital Era. Political Research Quarterly, 71(2), 482-494. https://doi.org/10.1177/1065912917744895

Gill, J. S., Breeze, J. L., \& Simopoulos, T. T. (2020). Pain Management Best Practices from Multispecialty Organizations During the COVID-19 Pandemic and Public Health Crises-Evaluating the Risk of Infection Associated with Corticosteroid Injections. Pain Medicine (Malden, Mass.), 21(8), 1730-1731. https://doi.org/10.1093/pm/pnaa167

Graneheim, U. H., Lindgren, B. M., \& Lundman, B. (2017). Methodological challenges in qualitative content analysis: A discussion paper. Nurse Education Today, 56(December 2016), 29-34. https://doi.org/10.1016/j.nedt.2017.06.002

Hoffmann, S., Weyer, J., \& Longen, J. (2017). Discontinuation of the automobility regime? An integrated approach to multi-level governance. Transportation Research Part A: Policy and Practice, 103, 391-408. https://doi.org/10.1016/j.tra.2017.06.016

Jones, K., Merrick, J., \& Beasley, C. (2016). A content analysis of oral health messages in Australian mass media. Australian Dental Journal, 61(1), 16-20. https://doi.org/10.1111/adj.12300

Khodarahmi, E. (2009). Crisis management. Disaster Prevention and Management: An International Journal, 18(5), 523-528. https://doi.org/10.1108/09653560911003714

Kozinets, R. V. (2015). Netnography. The International Encyclopedia of Digital Communication and Society, 1-8. https://doi.org/10.1002/9781118767771.wbiedcs067

Laasch, O. (2019). An actor-network perspective on business models: How 'Being Responsible' led to incremental but pervasive change. Long Range Planning, 52(3), 406-426. https://doi.org/10.1016/j.lrp.2018.04.002

Lau, H., Khosrawipour, V., Kocbach, P., Mikolajczyk, A., Schubert, J., Bania, J., \& Khosrawipour, T. (2020). The positive impact of lockdown in Wuhan on containing the COVID-19 outbreak in China. Journal of Travel Medicine, 27(3). https://doi.org/10.1093/jtm/taaa037

Liff, A. P., \& Erickson, A. S. (2017). From management crisis to crisis management? Japan's post-2012 institutional reforms and Sino-Japanese crisis (In)stability. Journal of Strategic Studies, 40(5), 604638. https://doi.org/10.1080/01402390.2017.1293530

Luscombe, A., \& Walby, K. (2017). Theorizing freedom of information: The live archive, obfuscation, and actor-network theory. Government Information Quarterly, 34(3), 379-387. https://doi.org/10.1016/j.giq.2017.09.003

Lytvynenko, V., Lurie, I., Radetska, S., Voronenko, M., Kornilovska, N., \& Partenjucha, D. (2017). Content analysis of some social media of the occupied territories of Ukraine. April 2017, 84-94. https://lens.org/116-199-493-907-951

Mahato, S., Pal, S., \& Ghosh, K. G. (2020). Effect of lockdown amid COVID-19 pandemic on air quality of the megacity Delhi, India. Science of the Total Environment, 730, 139086. https://doi.org/10.1016/j.scitotenv.2020.139086 
Modell, S., Vinnari, E., \& Lukka, K. (2017). On the virtues and vices of combining theories: The case of institutional and actor-network theories in accounting research. Accounting, Organizations and Society, 60, 62-78. https://doi.org/10.1016/j.aos.2017.06.005

Moretti, F., van Vliet, L., Bensing, J., Deledda, G., Mazzi, M., Rimondini, M., Zimmermann, C., \& Fletcher, I. (2011). A standardized approach to qualitative content analysis of focus group discussions from different countries. Patient Education and Counseling, 82(3), 420-428. https://doi.org/10.1016/j.pec.2011.01.005

Nicola, M., Alsafi, Z., Sohrabi, C., Kerwan, A., Al-Jabir, A., Iosifidis, C., Agha, M., \& Agha, R. (2020). The socio-economic implications of the coronavirus pandemic (COVID-19): A review. International Journal of Surgery, 78(April), 185-193. https://doi.org/10.1016/j.ijsu.2020.04.018

Noble, H., \& Smith, J. (2015). Issues of validity and reliability in qualitative research. Evidence-Based Nursing, 18(2), 34-35. https://doi.org/10.1136/eb-2015-102054

Putra, D. I., \& Matsuyuki, M. (2019). Disaster management following decentralization in Indonesia: Regulation, institutional establishment, planning, and budgeting. Journal of Disaster Research, 14(1), 173-187. https://doi.org/10.20965/JDR.2019.P0173

Sandlin, J. A. (2007). Netnography as a consumer education research tool. International Journal of Consumer Studies, 31(3), 288-294. https://doi.org/10.1111/j.1470-6431.2006.00550.x

Sheng, J., \& Lan, H. (2019). Business failure and mass media: An analysis of media exposure in the context of delisting event. Journal of Business Research, 97(July 2017), 316-323. https://doi.org/10.1016/j.jbusres.2018.01.055

Shim, Y., \& Shin, D. H. (2016). Analyzing China's Fintech Industry from the Perspective of ActorNetwork Theory. Telecommunications Policy, 40(2-3), 168-181. https://doi.org/10.1016/j.telpol.2015.11.005

Silalahi, D. E., \& Ginting, R. R. (2020). Strategi Kebijakan Fiskal Pemerintah Indonesia Untuk Mengatur Penerimaan dan Pengeluaran Negara Dalam Menghadapi Pandemi Covid-19. Jesya (Jurnal Ekonomi \& Ekonomi Syariah), 3(2), 156-167. https://doi.org/10.36778/jesya.v3i2.193

Strycharz, J., Strauss, N., \& Trilling, D. (2018). The role of media coverage in explaining stock market fluctuations: Insights for strategic financial communication. International Journal of Strategic Communication, 12(1), 67-85. https://doi.org/10.1080/1553118X.2017.1378220

Taekratok, T., Phanthunane, P., \& Taekratok, T. (2018). Disaster-based budgeting in new public health policy of Thailand. Procedia Engineering, 212(2017), 715-722. https://doi.org/10.1016/j.proeng.2018.01.092

Tavakoli, R., \& Wijesinghe, S. N. R. (2019). The evolution of the web and netnography in tourism: A systematic review. Tourism Management Perspectives, 29(August 2018), 48-55. https://doi.org/10.1016/j.tmp.2018.10.008

Vardarlier, P. (2016). Strategic Approach to Human Resources Management During Crisis. Procedia Social and Behavioral Sciences, 235(October), 463-472. https://doi.org/10.1016/j.sbspro.2016.11.057

Vladimirova, T. N., Vinogradova, M. V., Vlasov, A. I., \& Shatsky, A. A. (2019). Assessment of news items objectivity in mass media of countries with intelligence systems: The Brexit case. Media Watch, 10(3), 471-483. https://doi.org/10.15655/mw/2019/v10i3/49680

Whalen, E. A. (2018). Understanding a shifting methodology: A content analysis of the use of netnography in hospitality and tourism research. International Journal of Contemporary Hospitality Management, 30(11), 3423-3441. https://doi.org/10.1108/IJCHM-08-2017-0536 
Zapata-Barrero, R., Caponio, T., \& Scholten, P. (2017). Theorizing the 'local turn' in a multi-level governance framework of analysis: a case study in immigrant policies. International Review of Administrative Sciences, 83(2), 241-246. https://doi.org/10.1177/0020852316688426

\section{LIST OF MASS MEDIA:}

Almi Media. Langkah antisipasi PHK akibat pandemi COVID-19 dari segi hukum [Steps to anticipate layoffs due to the COVID-19 pandemic from a legal perspective], Retrieved on 13 August 2020 https://almi.or.id/

CNBC Indonesia. Jokowi Tambah Anggaran Pendidikan \& Kesehatan, Berapa Ya? [Jokowi has Increased the Education \& Health Budget, How Much?,], Retrieved on 15 August 2020 https://www.cnbcindonesia.com/

Detikom. Ini Enam Inti Aturan PSBB Serta Sanksi di Beberapa Wilayah [six core rules of Large-Scale Social Restrictions and sanctions in several Regions], Retrieved on 13 August 2020 https://news.detik.com

Detikom. Daftar 53 Kota/Kabupaten yang Masuk Zona Merah COVID-19 [A List of 53 Cities/Regencies Classified into the Covid-19 Red Zone], Retrieved on 15 August 2020. https://travel.detik.com/

Katadata. Pemerintah Siapkan Anggaran Penanganan Corona hingga 2022 [The Government has Prepared the Budget for handling the Covid-19 until 2022]

, downloaded on 22 August 2020. https://katadata.co.id/

Kompas, Rangkaian Peristiwa Pertama Covid-19 [The First Series of Covid-19 Incidents], Retrieved on 12 August 2020. https://bebas.kompas.id/

Kompas. Besaran BLT Dana Desa Naik Jadi Rp 2,7 Juta Per Keluarga [The amount of Direct Cash Assistance included to the Village Funds has been increased up to IDR 2.7 million per beneficiary family], Retrevied on 13 August 2020 https://money.kompas.com/

Kontan. BLT untuk pegawai akan diberikan mulai September 2020 [Direct Cash Assistance for employees will be given starting from September 2020], Retrieved on 18 August 2020 https://nasional.kontan.co.id/

Kumparan. New Normal Indonesia: Apa Sebenarnya Makna dari Istilah Tersebut? [New Normal Indonesia: What Does it Really Mean?], Retrieved in August 2020. https://kumparan.com/

Talenta. Kebijakan yang Sebaiknya Diterapkan Perusahaan Selama Wabah COVID-19 [Policies that Companies Should Implement during the Outbreak of Covid-19 Pandemic]. Retrieved on 18 August 2020 https://www.talenta.co/

Tirto. Bagaimana COVID-19 Mengubah Ekonomi Indonesia \& ASEAN? [How will Covid-19 Change the Indonesian \& ASEAN Economy?] Retrieved on 12 August 2020. https://tirto.id/ 